\title{
THE HEARSAY RULE IN CIVIL ANTITRUST SUITS*
}

By excluding from evidence intra- and inter-company communications not subject to cross-examination at the time they were made, the hearsay rule impedes fact-finding in civil antitrust suits. ${ }^{1}$ For in many cases such documents are the backbone of the Government's proof. ${ }^{2}$ Customers and

* United States v. United Shoe Machinery Corporation, 89 F. Supp. 349 (D. Mass. 1950). 1940).

1. On the hearsay rule generally, see 5 WigMroRe, EVIDENCE $\$ \S 1361-1365$ (3d ed.

Since civil antitrust suits are non-jury equity proceedings, equity rules of evidence are applied. It is uncertain whether the rules of evidence used in common law courts are applicable to equity suits. 1 WIGMORE, EvidENCE 171-3 (3d ed. 1940). Despite statements by some commentators that the rules of evidence in equity are identical with those at law, Green, The Admissibility of Evidence Under the Federal Rules, 55 HARv. L. REv. 197, 201 (1941) and Note, 46 CoL. L. REv. 268, 271-2 (1946), there are no clear appellate holdings on this matter. 3 Moore, Federal Practice $\$ 43: 02$ (1938). The lower federal courts in civil antitrust suits, however, have applied exclusionary rules. E.g., United States v. Aluminum Co. of America, 1 F.R.D. 48 (S.D. N.Y. 1938) (transcript of testimony taken in FTC hearing excluded); United States v. General Electric Co., 82 F. Supp. 753, 904 (D. N.J. 1949) (intra-company documents "whose authorship was never precisely determined . . ." excluded as hearsay); United States v. Schine Chain Theatres, 63 F. Supp. 229, 242 (W.D. N.Y. 1945) (certain inter-office communications excluded as hearsay). But see United States v. Vehicular Parking, Ltd., 52 F. Supp. 751, 755 (D. Del, 1943) (hearsay documentary evidence admitted without reference to whether it fulfills the requirements of an exception to the hearsay rule). See also, HaMimton \& TIIL, ANTITrost in Action 64 (TNEC Monograph 16, 1940).

The extent to which important intra-company documents are excluded is not fully reflected in the reported cases. In most suits the hearsay is excluded in the course of trial by a verbal ruling. If the government prevails in the trial court despite the rejection of the evidence, the issue is never again raised and the ruling does not appear in the reported decision of the court. Only where issue is fully joined-where large numbers of intra-company documents are challenged, or where the government does not prevail-does a ruling appear.

For one federal judge's attitude toward the hearsay rule in antitrust cases, see Yankwich, Observations on Antitrust Procedures, 10 F.R.D. 165, 169 (1950). The author advocates strict adherence to the recognized rules of evidence in antitrust suits-both civil and criminal-as a means of economizing time.

2. See McAllister, The Big Case: Procedural Problems in Antitrust Litigation, 64 HaRv. L. REv. 27, 32 (1950). See note 4 infra for typical cases in which intra-company documents were the back bone of the Government's case.

The following are examples of the use of intra- and inter-company communications in proving:

a) Intent to Monopolize: e.g., Hartford-Empire Co. et. al. v. United States, 323 U.S. 386,439 , n. 3 (1944) (inter-office memoranda deemed good evidence of defendants' intent); United States v. Corn Products Refining Company, 234 Fed. 964, 978 (S.D. N.Y. 1916) (inter-office communications held to be "cinematographic photographs" of intent).

b) Restraints of Trade: e.g., United States v. Schine Chain Theatres, 63 F. Supp. 229, 236 (1945) (defendant's employees' written statements admitted as evidence of threats and other unfair competitive practices); United States v. General Electric Co., 82 F. Supp. 753, 902-3 (D. N.J. 1949) (intra-company documents employed to demonstrate a pattern of practices detrimental to trade).

c) Conspiracy: e.g., American Tobacco Co. v. United States, 147 F.2d 93, 118 (6th Cir. 
competitors, unwilling to run the risk of economic reprisals, ${ }^{3}$ cannot always be relied on to testify against a dominant company. Corporate directors rarely make declarations which will clearly qualify as "admissions" of the corporation in an evidentiary sense. Thus, frequently the unlawful agreement or pattern of restraint can be proved only by documents of the defendant company or of its competitors or collaborators. ${ }^{4}$

Although the trend in antitrust cases is toward the admission of all relevant documentary evidence, ${ }^{5}$ federal courts have continued to apply the hearsay rule. ${ }^{6}$ Admissibility of documents has therefore depended on the Government's ability to pigeon-hole them under one of the conventional hearsay exceptions. ${ }^{7}$ In the recent civil antitrust case of United States $v$.

1944) (acts in furtherance of conspiracy proved by intra-company communications); United States v. General Electric Co., supra, at 903 (back-ground of facts out of which the alleged conspiracy arose proved by intra-company documents).

3. Economic reprisals may take various forms. As to the customers of a dominant company, long term business arrangements may suddenly be revised or rescinded, credit may be withheld, goods may arrive late or not at all. The return of goods by the customer, once taken for granted, may be subject to endless negotiation. Refusals to sell may occur. As to the competitor, costly patent infringement suits may be threatened or actually commenced. Price cutting may start. Pressure may be put on the suppliers of raw materials. See Hamilton \& TIIL, Antitrust in Actron 47 (TNEC Monograph 16, 1940).

4. For cases in which the government's allegations were proved almost exclusively by intra-company documents, see, e.g., United States v. General Electric Co., 82 F. Supp. 753, 902-3 (D. N.J. 1949); American Column \& Lumber Co. et al. v. United States, 257 U.S. 377, 392 (1921). HAMnLtoN \& TILL, op. cit. supra, note 1, at 54-55, describe various ways in which such documents may reflect an unlawful act: "[I]ncidental references, . . . discreet conversations, . . . tell-tale terms [are] scattered through the company's files. These fragments of testimony may be anywhere-in personal letters to officials alone, in inter-office memos seeking to implement the unexpressed pact. . . . Time and again a file lives with the atmosphere of an effective restraint, yet discloses nowhere the formal statement. As document follows document there is everywhere tacit acceptance of some understanding which remains mute."

5. See, e.g., United States v. General Electric Co., 82 F. Supp. 753, 903 (D. N.J. 1949): "Exaggerated and over refined niceties in the rules of evidence must give way to the broad terms of Rule 43(a) . . . if full effect to the anti-trust laws is to be given." See also United States v. General Motors Corp., 121 F.2d 376, 407-409 (7th Cir. 1941); United States v. Vehicular Parking Ltd., 52 F. Supp. 751, 754 (D. Del. 1943); United States v. Aluminum Co. of America, 35 F. Supp. 820, 823-5 (S.D. N.Y. 1940); Dession, The Trial of Economic and Technological Issues of Fact, 58 Y ALE L. J. 1019, 1242 et seq. (1949).

Rule 43(a) of the Federal Rules of Civil Procedure has also played a part in this trend. If the offered evidence is admissible under any federal statute, under any rule of evidence applied in equity courts, or under the rules of evidence applied in the courts of general jurisdiction in the state in which the court sits, it is admissible in the federal court. See 3 MoORe, Federal Practice $\S$ 43:01 (1938). Professor Moore believes that Rule 43(a) "revolutionizes federal evidence, and in general places admissibility upon the sole basis of relevancy and materiality." Id. at 3063. The cases decided under the rule, however, do not entirely support this view. See Green, The Admissibility of Evidence Under the Federal Rules, 55 HARv. L. REv. 197, 219-225 (1941); Note, 46 Col. L. Rev. 267 (1946); Note, 2 Stan. L. REv. 776 (1950).

6. See note 1 supra.

7. E.g., American Tobacco Co. v. United States, 147 F.2d 93, 118 (4th Cir. 1944) 
United Shoe Machinery Corporation, ${ }^{8}$ however, a federal district court announced a doctrine which would in part remove this element of chance. At least as to intra-company communications, the court would eliminate the hearsay rule in civil antitrust cases to the same extent that it is inoperative in Federal Trade Commission hearings.

The complaint in this case charged defendant with monopolizing interstate commerce in shoe machinery. To prove its allegations the Government offered in evidence thousands of intra-company communications. These consisted of field reports on the competitive status of shoe machinery, reports from United's operating departments to other departments and to the corporate directors, and lower-echelon policy recommendations. ${ }^{9}$ The defendant objected to the introduction of the documents chiefly on the ground that they were hearsay.

(correspondence between sales representative and his employer, defendant, allowed in evidence as an admission); United States v. General Motors Corp., 121 F.2d 376, 409 (7th Cir. 1941) (field representative's statements held admissible as regular business entries).

8. 89 F. Supp. 349 (D. Mass. 1950).

9. Sample documents:

Field reports:

"Outside Machine Installation Report. ..........

"Firm: Barker Shoe Co.

"Machine: (name of machine)

"Made by

"Remarks: We were aware that this customer has these machines" (of a competitor) on order and thought we could ward off their installation by putting in an additional Model $\mathrm{C}$ stitcher on peak load. This was done. ..." Government Trial Brief, Vol. X, 48 .

Memoranda:

"From......... to........

"Wire

"There is very little competition in wire. We have been able to replace practically all competitive Strapling Wire with our metal spools. . . ." Government Trial Brief, Vol. XV, 55.

Departmental Reports:

"Annual Report, Cutting Die Department

"We have outlined a plan for a new designed clicking machine . . . with the thought in view of having a machine ready to put out should any one develop a machine which would jeopardize our machines." Government Trial Brief, Vol. VIII, 1.

Recommendation:

"Annual Report, Heeling and Metallic Department. ............

"In summarizing the increased use of more competitive machinery, particularly that of the Rapid Shoe Machinery Company ... we . . . urge the adoption of some protective measures as we feel that if allowed to continue it will eventually land in shoe factories and would be a dangerous competitor." Government Trial Brief, Vol. VII, 437, 445. 
The court pointed out that even under an orthodox application of the hearsay rule, most of the documents could be admitted on one of two rationales. Some could be allowed in as extra-judicial admissions of the defendant, to which the hearsay rule does not apply. ${ }^{10}$ And while United Shoe did not expressly authorize or accept the statements in the documents, the court felt that it would be sufficient for the Government to prove that United had adopted them by implication-that is, to show that its business transactions and policy were based on them. ${ }^{11}$ Other documents could be admitted under a federal statutory exception for regular business entries. ${ }^{12}$ The statute demands that the memoranda be made in the regular course of business and that it be in the regular course of business to make them promptly, either at the time of the act or event recorded or shortly thereafter. The court felt that the documents probably could meet these requirements.

But although these rationales were available, the court did not rely on them. Instead, it held that in a civil antitrust suit the hearsay rule is inoperative with respect to intra-company documents. Judge Wyzanski saw

10. An extra-judicial admission is an out of court statement made by a party, or made by his agent and authorized or adopted by the party. Since the statement is the party's own, he has no right to object to the lack of opportunity to cross-examine, and the hearsay rule is inapplicable. 4 WIGMORE, EVIDENCE $\$ 1048$ (3d ed. 1940). In common parlance, admissibility under this rationale is said to be under an exception to the hearsay rule. It will be referred to as an exception. See, Morgan, Admissions As An Exception to the Hearsay Rule, 30 YALE L.J. 355 (1921).

The general rule is that statements made by an agent are admissions of the partyprincipal if the agent was authorized to make statements regarding the subject. RESTATEarent, Agency § 286 (1933); Packet Company v. Clough, 87 U.S. 528, 540 (1874). Some courts go further and admit the agent's statements as admissions of the principal if "naturally made in the course of the agency." Slifka v. Johnson, 161 F.2d 467, 469 (2d Cir. 1947), noted in 60 HARV. L. REv. 976 (1947). However, this is still the minority view. Mere authority to act is generally held not to include authority to make admissions, even if within the general framework of the agency. RESTATEMENT, AGENCY $\$ 288(1)$ (1933).

Furthermore, where the statement of the agent is not made to the outside world, as in the case of intra-company communications, the fact that the agent had authority to speak does not make the statement an admission of the company. RESTATEMENT, AGENCY \$ 287 (1933). The agent must have had authority not only to speak, but to commit the company by such statement, or the company must have adopted the statement after it was made. Morgan, Significant Developments in the Law During the War Years, Evidence, Practicing Law Institute Pampelet, 80 (1946). See also Lever Bros. Co. v. Atlas Assur. Co., 131 F.2d 770, 776 (7th Cir. 1942).

11. See 4 WiGMORE, EVIDENCE § 1073(4) (3d ed. 1940).

Although the court in the instant case felt certain that many of the documents had in fact been adopted by United Shoe through action in reliance, it stated that they would nevertheless not be received as an admission because the government had failed to meet the burden of showing actual reliance as to specific documents. $89 \mathrm{~F}$. Supp. 349,354 . Some of the documents were also inadmissible under the regular business entry exception. They were therefore saved for the fact-finding process only by the court's more sweeping abrogation of the hearsay rule.

12. 28 U.S.C. $\S 1732$ (1948). See generally 5 WrGMore, Evidence $\$ \S 1518,1520$ (3d ed. 1940); Comment, 46 MiCr. L. REv. 802 (1948). 
strong similarities between unfair competition proceedings in the Federal Trade Commission and civil antitrust suits before a court sitting without a jury. He felt that the substantive antitrust law is identical; that the order of the Commission may in many cases be as drastic as the decree of a court; ${ }^{13}$ and that the Government has the unfettered choice of prosecuting the case before either tribunal. Therefore he concluded that a court should apply the same rules of evidence as the Commission. ${ }^{14}$ Since trustworthy hearsay is regularly admitted in FTC hearings, it was admitted in this case. ${ }^{15}$

The United Shoe Machinery holding is eminently desirable in result. Although in that case the hearsay rule might have been avoided under a combination of two rationales, exceptions to the rule will not always be available. In the case of intra-company documents, for example, the exception for extra-judicial admissions requires proof that the defendant either expressly authorized or approved the documents, or conducted its business in such a way as to indicate adoption of them. But express authorization or approval is frequently made by a mere nod of the head or by a telephoned clearance-acts which are extremely difficult to prove. And proof of adoption by reliance apparently requires not only proof that the company followed a particular policy, but also an analysis of its decision-making process to show that it actually relied on the documents in following that policy. ${ }^{16}$

13. The court's decree and the Commission's order, Judge Wyzanski noted, are potentially identical in every respect except that the decree of the court can be used as prima facie evidence of monopoly in a private damage suit. 15 U.S.C. $\$ 16$ (1946). 89 F. Supp. 349, 356 (D. Mass. 1950). Apparently the court did not consider the difference significant. See text of note 27 infra, for an examination of the validity of this element of the court's analogy.

14. See FTC, Rules, Policy, Organization, and Acts 17 (1949) for the rules of evidence in the Commission. The only rule on the admissibility of evidence states: "The trial examiner ... shall admit relevant, material, and competent evidence. ..." In John Bene \& Sons v. Federal Trade Commission, 299 Fed. 468, 471 (2d Cir. 1924) the commission was held to be able to receive and rely on ". . . evidence or testimony . . . if of the kind that usually affects fair-minded men in the conduct of their daily and more important affairs. ..."

The courts have defined in very general terms the kind of hearsay evidence which the administrative agencies may admit. See International Association of Machinists v. NLRB, 110 F.2d 29, 35 (D.C. Cir. 1939), aff'd, 311 U.S. 72 (1940): "[I]t is only convincing, not lawyers' evidence which is required. . . . The evidence must be such as a reasonable mind might accept. . . " See also Gelimorn, Federal Adainistrative Procedure 80 (1941). A finding of fact by a federal administrative agency is rarely based wholly on hearsay. Chamberlain, Dowling, Hays, The Judictal Function in Federad adirimistrative AGENCIES 22-3 (1942).

15. The court pointed out another reason for eliminating the hearsay rule. It felt that in the face of the trend toward administrative adjudication of social and economic controversies- $a$ trend traceable in part to the relaxed rules of evidence in the agencies-the courts must relax the rigidity of the hearsay rule in order to preserve their own jurisdiction. 89 F. Supp. 349, 356.

16. It is uncertain that such a detailed showing is needed to prove an admission. In Chicago, St. Paul, M. \& O. Ry. v. Kulp, 102 F.2d 352, 356 (8th Cir. 1939) the mere making of a report to the company was sufficient to constitute an admission of the company. But as Judge Wyzanski points out, this view can hardly be said to have been established as a 
Such proof would consume much time, and in many cases might be wellnigh impossible.

The business entry exception may be equally unavailable. Admissibility under this exception has not been as liberal as the words of the statute would indicate. ${ }^{17}$ Shifting and narrow judicial definition of "business" and "regular course" may result in the exclusion of important intra-company documents. ${ }^{18}$ And if any part of a memorandum is based on the hearsay statements of third persons who are not acting in the regular course of business, the hearsay part of the document may be excluded. ${ }^{19}$ In a liberal application of the business entry rule, the court in the United Shoe Machinery case would have admitted the documents because they were made on forms regularly used by United's employees and regularly preserved in the company's files. ${ }^{20}$ In many cases, however, the incriminating communication will be made during a momentary crisis in the company's unlawful operations. ${ }^{21}$ Such a document may not be considered a regular entry. ${ }^{22}$

But despite the need for a rationale under which documentary hearsay can be admitted in civil antitrust suits, the one offered by Judge Wyzanski is dubious. In the first place, it is questionable whether in all civil antitrust suits the Government has an unfettered choice of going before the Federal Trade Commission or before a district court. ${ }^{23}$ It has never been authorita-

"rule of evidence heretofore applied in the courts of the United States on the hearing of suits in equity." $89 \mathrm{~F}$. Supp. $349,353$.

17. See generally, Note, 48 Col. L. Rev. 920 (1948); Comment, 46 Mrch. L. Rev. 802 (1948).

18. See, e.g., Palmer v. Hoffman, 318 U.S. 109 (1943). An accident report prepared by an employee of a railroad company was held not to be an entry in the regular course of business although it was conceded that the company regularly made such reports whenever an accident occurred. Id. at 113. The company's "business" was defined as the railroad business, not the making of accident teports. Id. at 111. "An accident report may affect that business in the sense that it affords information on which the management may act. It is not, however, typical of entries made systematically or as a matter of routine to record events or occurrences. . . ." Id. at 113.

19. E.g., Gencarella v. Fyfe, 171 F.2d 419, 422 (1st Cir. 1948).

20. 89 F. Supp. 349,354 .

21. Hamil ton \& Till, ANtirrust in Action 54 (TNEC Monograph 16, 1940): "Even where discipline is close, situations come from around the corner which fall a little outside the terms of the accord. . . . All may remain informal, documents may remain at a minimum-yet moments of strain come to every industry with an attendant lapse into communication."

22. Cf. New York Life Insurance Co. v. Taylor, 147 F.2d 297, 300 (D.C. Cir. 1945). The court defined the kind of documents admissible under the statute as those which "represent routine reflections of day-to-day operations." A report inspired by a crisis hardly meets that test. See 5 WIGMORE, EVIDENCE $§ 1548$ (3d ed. 1940): "A mere individual memorandum does not satisfy [the regularity requirement]."

23. The Federal Trade Commission is given authority by Section 5 of the FTC Act to prohibit "unfair methods of competition." 52 STAT. 111 (1938), 15 U.S.C. $\$ 45$ (1946), and by Section 11 of the Clayton Act to enforce its provisions. 38 Stat. 734 (1914), as amended, 15 U.S.C. $\$ 21$ (1946). The federal district courts are given equity jurisdiction by Section 4 of the Sherman Act, 26 Stat. 209 (1890), as amended, 36 Stat. 1167 (1911), 15 U.S.C. $\$ 4$ 
tively settled that the Commission has jurisdiction over a violation of Section 2 of the Sherman Act. The strongest authority on the point is a dictum by Justice Black in the Cement Institute case that "all conduct violative of the Sherman Act may likewise come within the unfair trade practice prohibitions of the Trade Commission Act . . ."24-an ambiguous statement at best. Equally doubtful is Judge Wyzanski's statement that in most cases an FTC cease and desist order may be as drastic as a court decree. There is an important difference between the powers of an equity court and those of the FTC in terms of what it can order a defendant to do. A federal district court sitting in equity can order dissolution of a monopolizing defendant or divestiture of one of its subsidiaries. ${ }^{25}$ But in FTC v. Eastman Kodak Co., ${ }^{26}$ the Supreme Court held that the Commission, in a proceeding under Section 5 of the FTC Act, had no authority to order Eastman to sell three of its laboratories. In the words of the court, the Commission "has not been delegated the authority of a court of equity." 27 Furthermore, the fact that a court decree, unlike a Commission order, can be used as prima facie evidence in a treble damage suit is hardly an insignificant difference. The amounts claimed in treble damage suits based on a court decision may run into millions of dollars. ${ }^{28}$

The real reason for relaxing the hearsay rule in civil antitrust cases is that intra- and inter-company communications meet the basic test for hearsay exceptions. This test requires (1) some measure of necessity or convenience, and (2) an alternative element of trust-worthiness to provide a substitute for cross-examination. ${ }^{29}$ The first requirement is satisfied in civil antitrust suits because documentary evidence is often the heart of the Government's

(1946) and Section 15 of the Clayton Act, 38 Stat. 736 (1914), 15 U.S.C. $\S 25$ (1946) over Sherman and Clayton Act violations.

24. Federal Trade Commission v. Cement Institute et al., 333 U.S. 683, 694 (1948) (Italics supplied.)

25. E.g., Standard Oil of New Jersey v. United States, 221 U.S. 1, 77-79 (1911) (divestiture ordered); United States v. Paramount Pictures Inc., 85 F. Supp. 881,899 (S.D. N.Y. 1949) (remedy proceeding, divorcement ordered.) See generally, Berge, Remedies Available to the Government under the Sherman Act, 7 LAW \& ConTEMP. PROB. 1, 104-111 (1940); Hale, Trust Dissolution: "Atomizing" Business Units of Monopolistic Size, 40 CoL. L. REv. 615 (1940).

26. 274 U.S. 619 (1927).

27. Id. at 623 .

28. It has been reported, for example, that treble damage suits aggregating over 100 million dollars have been filed against the eight major defendants in the Paramount case. 56 BOX OFFICE 7 (Feb. 18, 1950).

29. 5 WigMORE, EvIDENCE $\S \S 1420-1422$ (3d ed. 1940); Morgan, Admissions as an Exception to the Hearsay Rule, 30 YALE L.J. 355, 360 (1921) (setting up the requirements for an exception to the hearsay rule).

See also, United States v. Wescoat, 49 F.2d 193, 195 (4th Cir. 1931) (necessity and circumstantial guaranty of trustworthiness lets hearsay evidence in); United States v. Aluminum Company of America, 35 F. Supp. 820, 823-4 (S.D. N.Y. 1940) (a concededly hearsay document admitted because it was held to be necessary-the only evidence on the pointand trustworthy). 
case. Aside from the difficulty which the Government faces in procuring oral testimony, the documents of the defendant and of its competitors may well constitute the most accurate record of past business practices. ${ }^{30}$ The second prerequisite - that of trustworthiness-is met because such documents are widely relied on in the business world. There is no reason why courts should shut their eyes to communications which form the basis of day-to-day business decisions. Of course some documents may be less trustworthy than others. But the judge can take that into account when he evaluates the revidence. For the admission of a document does not mean that it must be relied on; the test, even in administrative agencies, is that evidence be "of the kind that usually affects fair-minded men in the conduct of their daily and more important affairs." 31

It should also be noted that in any civil antitrust suit the judge, who is both umpire on the admissibility of evidence and trier of the facts, will read and inevitably be influenced by the documents offered, whether they are admitted or not. ${ }^{32}$ Furthermore, abrogating the hearsay rule in its strict form will not unduly burden an antitrust defendant. For the Government's access to, and analysis of, intra- and inter-company documents is necessarily that of an outsider. ${ }^{33}$ The defendant, as an insider, is able to produce from his files explanatory documents which either nullify incriminating evidence or place it in the proper context. ${ }^{34}$ In this way, the defendant can neutralize any evidence which does not accurately reflect the company's operations.

Given these basic reasons for liberalizing the hearsay rule in civil antitrust cases, Judge Wyzanski's analogy between proceedings in the FTC and in the courts-despite its shortcomings-becomes a useful legal makeweight. But it is no more than that. The real considerations underlying a relaxation of the hearsay rule in such cases exist quite apart from any such analogy. It is to be hoped that other federal courts, realizing this, will expand upon the forthright lead of Judge Wyzanski and hold that in civil antitrust suits all relevant documents may come in for what they are worth.

30. HAMrLton \& TiLl, ANTitrust in Action 64 (TNEC Monograph 16, 1940): "[T]hey are among the most accredited material upon whose foundation corporate policies are posited."

31. John Bene \& Sons v. Federal Trade Commission, 299 Fed. 468, 471 (2d Cir. 1924).

32. Cf. Donnelly Garment Co. v. NLRB, 123 F.2d 215, 224 (8th Cir. 1941): "One who is capable of ruling accurately on the admissibility of evidence is equally capable of sifting it accurately after it has been received. . .."

33. For an excellent analysis of the problems faced by the Antitrust Department in obtaining intra-company documents, see Hamition \& Till, AnTitrust in Action 45-6, 50-51 (TNEC Monograph 16, 1940).

34. See Dession, The Trial of Economic and Technological Issues of Fact, 58 YALE L.J. 1019, 1024 (1949). 